\title{
APC Gene Mutation
}

National Cancer Institute

\section{Source}

National Cancer Institute. APC Gene Mutation. NCI Thesaurus. Code C134473.

A change in the nucleotide sequence of the APC gene. 